\title{
Phenology and thermal requirements of grapevine cultivars in Dois Vizinhos, Paraná State, Brazil
}

\section{Josiane Aparecida Mariani1 ${ }^{*}$ (D) Gilmar Antônio Nava ${ }^{1}$ iD Dalva Paulus $^{1}$ (D}

${ }^{1}$ Programa de Pós-graduação em Agroecossistemas (PPGSIS), Universidade Tecnológica Federal do Paraná (UFPR), Campus Dois Vizinhos, 89801015, Chapecó, SC, Brasil. E-mail: josiane_mariani@hotmail.com. *Corresponding author.

\begin{abstract}
This study aimed to characterize the phenology and thermal requirements of grapevine cultivars Bordo, BRS Carmem, BRS Lorena, BRS Magna, BRS Rubea, BRS Violeta, Concord, Concord Clone 30, Isabel, Isabel Precoce, Moscato Bailey, Moscato Embrapa, Niagara Branca, Niagara Rosada, and Seibel 5455 grafted on Paulsen 1103. The study was conducted in the fruit growing sector of the Federal Technological University of Paraná, Câmpus Dois Vizinhos, Paraná State, Brazil, during the cycles of 2015/2016 and 2016/2017. The experimental design was completely randomized, with four replicates and two evaluated plants per plot. Plants were grown in a vertical trellis system and spur pruned with two buds. Evaluations of phenology and thermal requirements were carried out from pruning to harvest. Cultivars Moscato Bailey and Seibel 5455 had high thermal requirements and longer cycles, while cultivars BRS Magna, BRS Violeta, and Isabel Precoce had lower thermal requirements and shorter cycles. The cycle and the thermal requirements of cultivars ranged from 98 to 132 days, and from 1065 to 1548 degree-days, respectively.
\end{abstract}

Key words: Vitis labrusca, hybrids, cycle, heat.

Fenologia e requerimento térmico de cultivares de videiras em Dois Vizinhos, PR, Brasil

RESUMO: Este trabalho objetivou caracterizar a fenologia e o requerimento térmico das cultivares de videiras Bordô, BRS Carmem, BRS Lorena, BRS Magna, BRS Rubea, BRS Violeta, Concord, Concord Clone 30, Isabel, Isabel Precoce, Moscato Bailey, Moscato Embrapa, Niagara Branca, Niagara Rosada e Seibel 5455, sobre o porta-enxerto Paulsen 1103. A pesquisa foi realizada no setor de fruticultura da Universidade Tecnológica Federal do Paraná, Campus de Dois Vizinhos, durante as safras 2015/2016 e 2016/2017. O delineamento experimental foi inteiramente ao acaso, com quatro repetições e duas plantas úteis por parcela. As plantas foram conduzidas em espadeira em cordão esporonado com poda curta em duas gemas. As avaliações de fenologia e exigências térmicas foram realizadas desde a poda até a colheita. As cultivares Moscato Bailey e Seibel 5455 possuem maiores requerimentos términos e ciclos mais tardios, enquanto BRS Magna, BRS Violeta e Isabel Precoce possuem menores requerimentos térmicos e ciclos mais precoces. O ciclo e o requerimento térmico das cultivares variou de 98 a 132 dias, e de 1065 a 1548 graus-dia, respectivamente.

Palavras-chave: Vitis labrusca, hibridos, ciclo e calor.

\section{INTRODUCTION}

In viticulture, knowledge of phenology is essential since it allows for characterization of the duration of the stages of development of the vine in relation to the climate. When coupled with knowledge of the thermal requirement of each cultivar, knowledge of phenology allows for secure planning of implementation of specific cultivars locally, and in other regions with similar climatic conditions. So, it possible to pre-determine the best time to prune and harvest the grapes (NUNES et al., 2016).
In tropical and subtropical regions of Brazil, there is the possibility of obtaining two or more annual grape harvests, while in cold climate regions, no more than one annual harvest is possible due to the prolonged occurrence of low temperatures during autumn and winter. This is the case in subtropical climate regions such as Rio Grande do Sul, Santa Catarina, and southwestern Paraná, where vineyards produce only a single harvest per year (GIOVANINNI, 2008).

In order to expand the harvest period, as well as produce good quality grapes and achieve 
good productivity, it is pertinent to understand the phenological stages of grapevines (JUBILEU et al., 2010), including dormancy (winter), sprouting, blooming, fruiting, growth of berries (spring), ripening and harvest (summer), until the fall of the leaves (autumn) (MANDELLI et al., 2009). These phenological stages can be influenced by meteorological conditions such as air temperature, precipitation, relative humidity, and hours of sunshine. These meteorological factors interact with the other components of the production system, influencing the development, production, and quality of the grapes and their derivatives (BACHK et al., 2013).

To complete their production cycle, vines requires a certain amount of energy, usually expressed in degree-days, which is the accumulated difference between daily mean temperature and basal temperature, below which the plants cannot develop (SOUZA et al., 2009). Application of degree-days as an indicator of the thermal requirements for grapevines has been studied by several authors (LEÃO \& SILVA, 2003; FERREIRA et al., 2004; ROBERTO et al., 2005; SANTOS et al., 2007; NEIS et al., 2010; BRIGHENTI et al., 2013).

According to SANTOS et al. (2007), and NUNES et al. (2016), for the vine cultivars of Brazil, the mean basal temperature which best characterizes the thermal requirements during vegetative development is $10^{\circ} \mathrm{C}$.

The objective of this study was to evaluate the phenology, thermal requirements, and the cycle of grapevine cultivars (Vitis labrusca and hybrids) in subtropical climate.

\section{MATERIALS AND METHODS}

This study was conducted in the fruit growing sector of the Federal Technological University of Paraná, Câmpus Dois Vizinhos, Paraná State, Brazil (2545'00”S latitude $53^{\circ} 03^{\prime} 25^{\prime \prime} \mathrm{W}$ longitude). The climate of the region is humid subtropical $C f a$, according to the Köppen classification, with an average temperature of $22^{\circ} \mathrm{C}$ in the warmest months, and an average temperature below $18{ }^{\circ} \mathrm{C}$ in the coldest months. The area has an average precipitation of 2,025 $\mathrm{mm}$ per year (ALVARES et al., 2013).

The following cultivars were evaluated: Bordô, BRS Carmen, BRS Lorena, BRS Magna, BRS Rubea, BRS Violeta, Concord, Concord Clone 30, Isabel, Isabel Precoce, Moscato Bailey, Moscato
Embrapa, Niagara Branca, Niagara Rosada, and Seibel 5455.

Two cycles were assessed, namely 2015/2016 and 2016/2017, in vineyards planted in August 2012, with a spacing of $1.5 \mathrm{~m} \times 2.3 \mathrm{~m}$. Plants were grown in a vertical trellis system with four levels of wires, and the double intermediate wires were distanced $12 \mathrm{~cm}$ apart. The canes were spur pruned with two buds, and trained in a cordon system $0.9 \mathrm{~m}$ above the ground.

The collection of vines was managed according to agroecological precepts. Fruit pruning was carried out on August $7^{\text {th }}, 2015$ and August $17^{\text {th }}$, 2016. After pruning, Sulphocalcic syrup $(5.0 \%)+$ mineral oil (Assist ${ }^{\mathbb{Q}}, 2.0 \%$ ) was applied to control scale insects, and to stimulate sprout failure in the arms of production of the vines. In the summer, Bordeaux $(20.0 \% \mathrm{Cu}, 10.0 \% \mathrm{~S}, 3.0 \% \mathrm{Ca})$ and Viçosa $\left(8.0 \% \mathrm{~K}_{2} \mathrm{O} ; 0.8 \% \mathrm{Mg}, 8.0 \% \mathrm{~S}, 9.0 \% \mathrm{Cu}, 3.0 \% \mathrm{Zn}\right.$, $3.0 \%$ B) syrup and copper hydroxide (Supera) were used for disease prevention and control.

The plants were fertilized with natural phosphate $\left(\right.$ Yorin $\left.^{\circledR}\right)$, vegetal ash, and organic compost consisting of poultry manure, following soil and leaf analyses. The soil was permanently managed with green and dead cover for the control of invasive plants. The soil was also managed for the nutritional supply of the vines, through symbiotic fixation of nitrogen and decomposition of dry matter, achieved by planting jack beans, Canavalia ensiformis, in the summer. The winter soil cover, consisting of a local grass, Avena strigosa, and common vetch, Vicia sativa, were sown in May of each year.

For phenological characterization, the plants were evaluated weekly from pruning to fruiting. Vegetative cycle of the vines was assessed according to the sub-periods adapted to that proposed by BLOESCH \& VIRET (2008), including: a) from pruning until the beginning of sprouting (BS), when the plants reach $50 \%$ of buds, with exteriorization of the first leaves; b) from the beginning of sprouting to full blooming (FB), considering $50 \%$ of the shoots with bunches in full bloom; c) from full bloom to the beginning of ripening (BR), when $50 \%$ of berries have changed color to red grapes, or when they became soft and translucent for the white cultivars; d) from the beginning of ripening to harvest, which was held when all cultivars obtained a soluble solids content above $16^{\circ}$ Brix; e) from the beginning of sprouting to harvest of the cultivars, obtaining the total cycle in days.

We obtained meteorological data from the station of the National Institute of Meteorology, 
located less than $500 \mathrm{~m}$ from the study site (INMET, 2017). For characterization of thermal requirements of the cultivars, the sum of degree-days (DD) was used, from pruning until harvest. The calculations of DD were performed according to the equation proposed by VILLA NOVA et al. (1972), adopting the basal temperature of $10^{\circ} \mathrm{C}$ (SENTELHAS, 1998), for every cycle of grapevines, as follows:

$\mathrm{DD}=(\mathrm{Tmin}-\mathrm{Tb})+\frac{\mathrm{Tmax}-\mathrm{Tmin}}{2}$

where: Tmax $=$ daily maximum temperature $\left({ }^{\circ} \mathrm{C}\right)$; Tmin $=$ daily minimum temperature $\left({ }^{\circ} \mathrm{C}\right), \mathrm{Tb}=$ basal temperature $\left({ }^{\circ} \mathrm{C}\right)$; and $\mathrm{ND}=$ number of days for the duration of each sub-period.

The experimental design was completely randomized with four repetitions, and each plot consisted of four plants (two border plants and two plants used in the assessments), in a bi-factor model. The 15 tested cultivars were included as factor 1 , and the two cycles (2015/2016 and 2016/2017) were included as factor 2. Data were analyzed using analysis of variance (ANOVA), and, when significant, the averages were grouped according to the Scott-Knott test at 5\% probability of error, using the statistical program Genes (CRUZ, 2006).

\section{RESULTS AND DISCUSSION}

The highest thermal requirement from pruning $(\mathrm{P})$ to the beginning of sprouting (BS) in the $2015 / 2016$ harvest year was observed in cultivar BRS Carmen (336 DD), which differed statistically from the remaining cultivars. In the 2016/2017 harvest year, the cultivars that required more heat from $\mathrm{P}$ to BS were BRS Carmen (225 DD), BRS Rubea (194 DD), and Niagara Branca (181 DD).

Regarding the two evaluated cycles, the $2015 / 2016$ harvest year had a greater thermal requirement for $\mathrm{BS}$, since this year had a less cold winter than the 2016/2017 harvest year. Another factor that may have contributed to reducing the estimated heat requirement in the 2016/2017 harvest year was the time of pruning, which was 10 days later than in the 2015/2016 harvest year.

According to PERUZZO et al. (2014), the estimated cold winter requirement for overcoming the state of dormancy in buds of the cultivars Bordô, Concord, Isabel, and Niagara Rosada is 50 hours below $7{ }^{\circ} \mathrm{C}$ and 140 hours below $10{ }^{\circ} \mathrm{C}$, which did not occur in the $2015 / 2016$ harvest year.

It is noteworthy that the cultivars that sprout later usually require more cold conditions during the winter, and since this requirement is not fully met in the southwest region of Paraná, it is possible that these cultivars require more heat to sprout. However, CITADIN et al. (2001) reported the opposite in peach trees, in which an increase in cold conditions reduced the peach trees' heat requirement to start budding.

In Dois Vizinhos, 28 hours and 185 hours of cold conditions, with temperatures below $7.2{ }^{\circ} \mathrm{C}$ were recorded, from May to August of 2015 (NAVA, 2015) and 2016, respectively, demonstrating that the winter of 2016 was much more suitable for interrupting dormancy of the vine buds.

For the phenological stage of BS to fully blooming (FB), the cultivars in the 2015/2016 cycle that required more heat were BRS Rubea (442 DD), Moscato Bailey (434 DD), and Moscato Embrapa (430 DD), which differed statistically from the other cultivars. In the 2016/2017 cycle, cultivars BRS Magna (352 DD), BRS Rubea (287 DD), Moscato Bailey (311 DD), and Moscato Embrapa (334 DD) required more heat, unlike the remaining cultivars; although, there were no statistical differences between the two distinct groups (Table 1).

During blooming, according to MANDELLI et al. (2009), the occurrence of low temperatures (below $15^{\circ} \mathrm{C}$ ) and/or humid and rainy days is quite detrimental, as it hinders flowering, and causes flaws in fruiting, resulting in thin bunches with nonuniform berries, which did not occur in this study. An efficient and regular plant health check is also necessary during the blooming stage, mainly to prevent anthracnosis.

As shown in table 2, there was an interaction between the factors studied for the FB-beginning of ripening (BR) sub-period, where the cultivar that had the lowest thermal requirement in the 2015/2016 cycle was BRS Violeta (494 DD), which differed significantly from the other cultivars. In the 2016/2017 harvest year, the cultivars with the lowest thermal requirement were BRS Magna (434 DD) and BRS Violeta (467 DD). There was no statistical difference in the averages of thermal requirements of cultivars between two cycles.

According to MANDELLI et al. (2003), the FB-BR sub-period is the period with the longest and highest thermal requirement, since this sub-period encompasses the complete formation of the flowers, fertilization, and formation of berries, which was also reported in this study.

There was an interaction between the factors studied for the BR-Harvest $(\mathrm{H})$ sub-period, 
Table 1 - Thermal requirements (degree-days) between pruning and the beginning of sprouting (P-BS) and beginning of sprouting to fully blooming (BS-FB) of the different grapevine cultivars, in the 2015/2016 and 2016/2017 cycles. Universidade Tecnológica Federal do Paraná, Dois Vizinhos, Paraná State, Brazil, 2018.

\begin{tabular}{|c|c|c|c|c|c|c|}
\hline \multirow[t]{2}{*}{ Cultivar/Cycle } & \multicolumn{3}{|c|}{---------------------------P-BS---------------------- } & \multicolumn{3}{|c|}{ 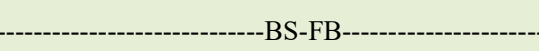 } \\
\hline & $15 / 16$ & $16 / 17$ & Average & $15 / 16$ & $16 / 17$ & Average \\
\hline Bordô & $165 \mathrm{cA}^{*}$ & $129 \mathrm{bA}$ & 147 & 299 bA* $^{*}$ & $240 \mathrm{bA}$ & 269 \\
\hline BRS Carmem & $336 \mathrm{aA}$ & $225 \mathrm{aB}$ & 280 & $317 \mathrm{bA}$ & $194 \mathrm{bB}$ & 255 \\
\hline BRS Lorena & $211 \mathrm{cA}$ & $174 \mathrm{bA}$ & 192 & $334 \mathrm{bA}$ & $267 \mathrm{bA}$ & 300 \\
\hline BRS Magna & $296 \mathrm{bA}$ & $156 \mathrm{bB}$ & 226 & $173 \mathrm{bB}$ & $352 \mathrm{aA}$ & 263 \\
\hline BRS Rubea & $237 \mathrm{cA}$ & $194 \mathrm{aA}$ & 216 & $442 \mathrm{aA}$ & $287 \mathrm{aB}$ & 364 \\
\hline BRS Violeta & $284 \mathrm{bA}$ & $146 \mathrm{bB}$ & 215 & $278 \mathrm{bA}$ & $258 \mathrm{bA}$ & 268 \\
\hline Concord & $280 \mathrm{bA}$ & $149 \mathrm{bB}$ & 215 & $317 \mathrm{bA}$ & $216 \mathrm{bB}$ & 266 \\
\hline Concord Clone 30 & $258 \mathrm{cA}$ & $159 \mathrm{bB}$ & 208 & $306 \mathrm{bA}$ & $209 \mathrm{bB}$ & 257 \\
\hline Isabel & $235 \mathrm{cA}$ & $158 \mathrm{bB}$ & 196 & $284 \mathrm{bA}$ & $246 \mathrm{bA}$ & 265 \\
\hline Isabel Precoce & $248 \mathrm{cA}$ & $142 \mathrm{bB}$ & 195 & $245 \mathrm{bA}$ & $234 \mathrm{bA}$ & 240 \\
\hline Moscato Bailey & $199 \mathrm{cA}$ & $138 \mathrm{bB}$ & 169 & $434 \mathrm{aA}$ & $311 \mathrm{aB}$ & 372 \\
\hline Moscato Embrapa & $226 \mathrm{cA}$ & $139 \mathrm{bB}$ & 182 & $430 \mathrm{aA}$ & $334 \mathrm{aB}$ & 382 \\
\hline Niagara Branca & $273 \mathrm{bA}$ & $181 \mathrm{aB}$ & 227 & $326 \mathrm{bA}$ & $207 \mathrm{bB}$ & 267 \\
\hline Niagara Rosada & $235 \mathrm{cA}$ & $163 \mathrm{bB}$ & 199 & $281 \mathrm{bA}$ & $227 \mathrm{bA}$ & 254 \\
\hline Seibel 5455 & $277 \mathrm{bA}$ & $156 \mathrm{bB}$ & 216 & $303 \mathrm{bA}$ & $229 \mathrm{bA}$ & 266 \\
\hline Average & 250 & 160 & 205 & 317 & 254 & 285 \\
\hline CV $(\%)$ & ------------ & -14.15 & ------------- & ------------ & ------23. & ------ \\
\hline
\end{tabular}

"Means followed by the same lowercase letter in columns and the same uppercase letter in rows are not significantly different from each other, based on the Scott-Knott test at 5\% probability of error. CV $=$ coefficient of variation.

where the cultivars BRS Magna (440 DD), BRS Violeta (403 DD), and Seibel 5455 (390 DD) had greater thermal requirements in the 2015/2016 cycle, while cultivars BRS Lorena (288 DD), BRS Rubea (288 DD), Concord (288 DD), Isabel Precoce (237 DD), Moscato Bailey (264 DD), and Moscato Embrapa (195 DD) required less heat in the same year. In the 2016/2017 cycle, the highest thermal requirement was observed for cultivars BRS Rubea (409 DD) and BRS Violeta (409 DD), while cultivars BRS Lorena (211 DD), Isabel Precoce (216 DD), and Niagara Rosada (204 DD) required less heat (Table 2).

MANDELLI et al. (2004) mention that weather conditions, nutritional status and health of the plant, amount of buds, plant conduction system, among other factors, have an effect on the date of ripening of the grapes.

Conversely, the harvest is directly linked to weather conditions occurring in the days prior to its execution. Excess rainfall stimulates the development of diseases (rotting of bunches and berries), reduces the quality of grapes, and increases the rates of attacks by insects, especially bees and wasps, which particularly affects the most sensitive cultivars (BARDHAN et al., 2011). However, if weather conditions are favorable to ripening, the date of collection can be delayed in order to obtain a better quality product.

Hence, the data demonstrate that local environmental conditions were inadequate, in particular with regards to excess water during ripening of the grapes, and the need for an early harvest, due to attacks by wasps and bees during the 2015/2016 cycle. According to BACK et al. (2013), vines can be cultivated without irrigation based on a precipitation of 500 to $600 \mathrm{~mm}$ per year, and high rainfall precipitation during the period of blooming causes flaws in fruiting, as well as rotting of the fruits, and consequent loss of quality, something also found during the 2015/2016 cycle in this study.

As shown in figure 1A, during the 2015/2016 harvest year, there was excess precipitation from the beginning of ripening to harvest, with a total precipitation of $683 \mathrm{~mm}$. The precipitation fell mainly 
Table 2 - Thermal requirement (degree-days) between fully blooming and beginning of ripening (FB-BR) and beginning of ripening and harvest (BR-H) of the different grapevine cultivars, in the 2015/2016 and 2016/2017 cycles. Universidade Tecnológica Federal do Paraná, Dois Vizinhos, Paraná State, Brazil, 2018.

\begin{tabular}{|c|c|c|c|c|c|c|}
\hline \multirow[t]{2}{*}{ Cultivar/Cycle } & \multicolumn{3}{|c|}{ 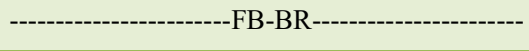 } & \multicolumn{3}{|c|}{ 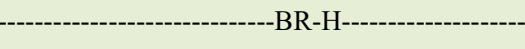 } \\
\hline & $15 / 16$ & $16 / 17$ & Average & $15 / 16$ & $16 / 17$ & Average \\
\hline Bordô & $(-)$ & $(-)$ & $(-)$ & $(-)$ & $(-)$ & $(-)$ \\
\hline BRS Carmem & $787 \mathrm{aA}^{*}$ & $835 \mathrm{bA}$ & 811 & $366 \mathrm{bA}^{*}$ & $343 \mathrm{bA}$ & 355 \\
\hline BRS Lorena & $897 \mathrm{aA}$ & $891 \mathrm{aA}$ & 894 & $288 \mathrm{cA}$ & $211 \mathrm{~dB}$ & 249 \\
\hline BRS Magna & $599 \mathrm{bA}$ & $434 \mathrm{eB}$ & 516 & $440 \mathrm{aA}$ & $330 \mathrm{bB}$ & 385 \\
\hline BRS Rubea & $783 \mathrm{aA}$ & $813 \mathrm{bA}$ & 798 & $288 \mathrm{cB}$ & 409 aA & 348 \\
\hline BRS Violeta & $494 \mathrm{cA}$ & $467 \mathrm{eA}$ & 480 & $403 \mathrm{aA}$ & 409 aA & 406 \\
\hline Concord & $816 \mathrm{aA}$ & 879 aA & 847 & $288 \mathrm{cA}$ & $315 \mathrm{bA}$ & 301 \\
\hline Concord Clone 30 & $805 \mathrm{aA}$ & $738 \mathrm{cA}$ & 772 & $334 \mathrm{bA}$ & $295 \mathrm{cA}$ & 314 \\
\hline Isabel & $818 \mathrm{aB}$ & $962 \mathrm{aA}$ & 890 & $345 \mathrm{bA}$ & $287 \mathrm{cB}$ & 316 \\
\hline Isabel Precoce & $822 \mathrm{aA}$ & $673 \mathrm{~dB}$ & 747 & $237 \mathrm{cA}$ & $216 \mathrm{dA}$ & 226 \\
\hline Moscato Bailey & $787 \mathrm{aB}$ & $893 \mathrm{aA}$ & 840 & $264 \mathrm{cA}$ & $287 \mathrm{cA}$ & 275 \\
\hline Moscato Embrapa & $929 \mathrm{aA}$ & $859 \mathrm{aB}$ & 894 & $195 \mathrm{cB}$ & $287 \mathrm{cA}$ & 241 \\
\hline Niagara Branca & $695 \mathrm{aA}$ & $756 \mathrm{cA}$ & 726 & $338 \mathrm{bA}$ & $268 \mathrm{cB}$ & 303 \\
\hline Niagara Rosada & $814 \mathrm{aA}$ & $827 \mathrm{bA}$ & 820 & 377 bA & $204 \mathrm{~dB}$ & 290 \\
\hline Seibel 5455 & $855 \mathrm{aB}$ & $954 \mathrm{aA}$ & 904 & $390 \mathrm{aA}$ & $365 \mathrm{bA}$ & 377 \\
\hline Average & 778 & 784 & 781 & 325 & 302 & 313 \\
\hline CV $(\%)$ & ------------- & $---7.92--$ & ------------ & ------------- & -------1 & -------- \\
\hline
\end{tabular}

*Means followed by the same lowercase letter in columns and followed by the same uppercase letter in rows are not significantly different from each other, based on the Scott-Knott test at 5\% probability of error. (-) absence of production, CV $=$ coefficient of variation.

in December, with more than $350 \mathrm{~mm}$ recorded. In contrast, in the 2016/2017 cycle, around $340 \mathrm{~mm}$ of precipitation was recorded in November, December, and January (Figure 1B).

Table 3 presents the period in days (full cycle) and the total thermal requirement between BS and $\mathrm{H}$. This information is important for planning the feasibility of using a cultivar in a certain region, as well as for the prediction of harvests (MANDELLI et al., 2003).

The period of days in BS-H required for the cultivar Moscato Bailey (132 days) was longer in the 2015/2016 cycle; although, it was shortest for the cultivars BRS Magna (98 days) and BRS Violeta (99 days). In the 2016/2017 cycle, the cultivar with the longest cycle was Seibel 5455 (146 days), and the cultivar with the shortest cycle was BRS Magna (98 days).

Regarding the total thermal requirement of each cultivar, there were statistical differences between cultivars. In the 2015/2016 cycle, the cultivars that required the least heat were BRS Magna (1,213 DD) and BRS Violeta (1,175 DD), which differed statistically from the others. In the 2016/2017 cycle, the cultivars that required the least heat were BRS Magna (1,116 DD), BRS Violeta (1,136 DD), Concord (1,065 DD), and Isabel Precoce $(1,125$ DD), which were not statistically different from each other, but did differ significantly from the other cultivars.

In the literature, little information is available on the cycle and thermal requirement for grapevine cultivars included in this study, and available information varies according to the cultivation sites. According to CARVALHO (2016), under the edaphoclimatic conditions of Lavras, Minas Gerais State, Brazil, the cultivars Isabel Precoce and BRS Violeta had the shortest cycles, with a cycle of 107 days and a thermal requirement of 1,200 degreedays. These results are very similar to those obtained in this study for the same cultivars. The same authors reported that the cultivars Isabel and Concord had longer cycles and required 1,512 and 1,483 degreedays, with cycles of 130 and 128 days, respectively, which partially agrees with the results obtained in the current study. Previously, NUNES et al. (2016) 


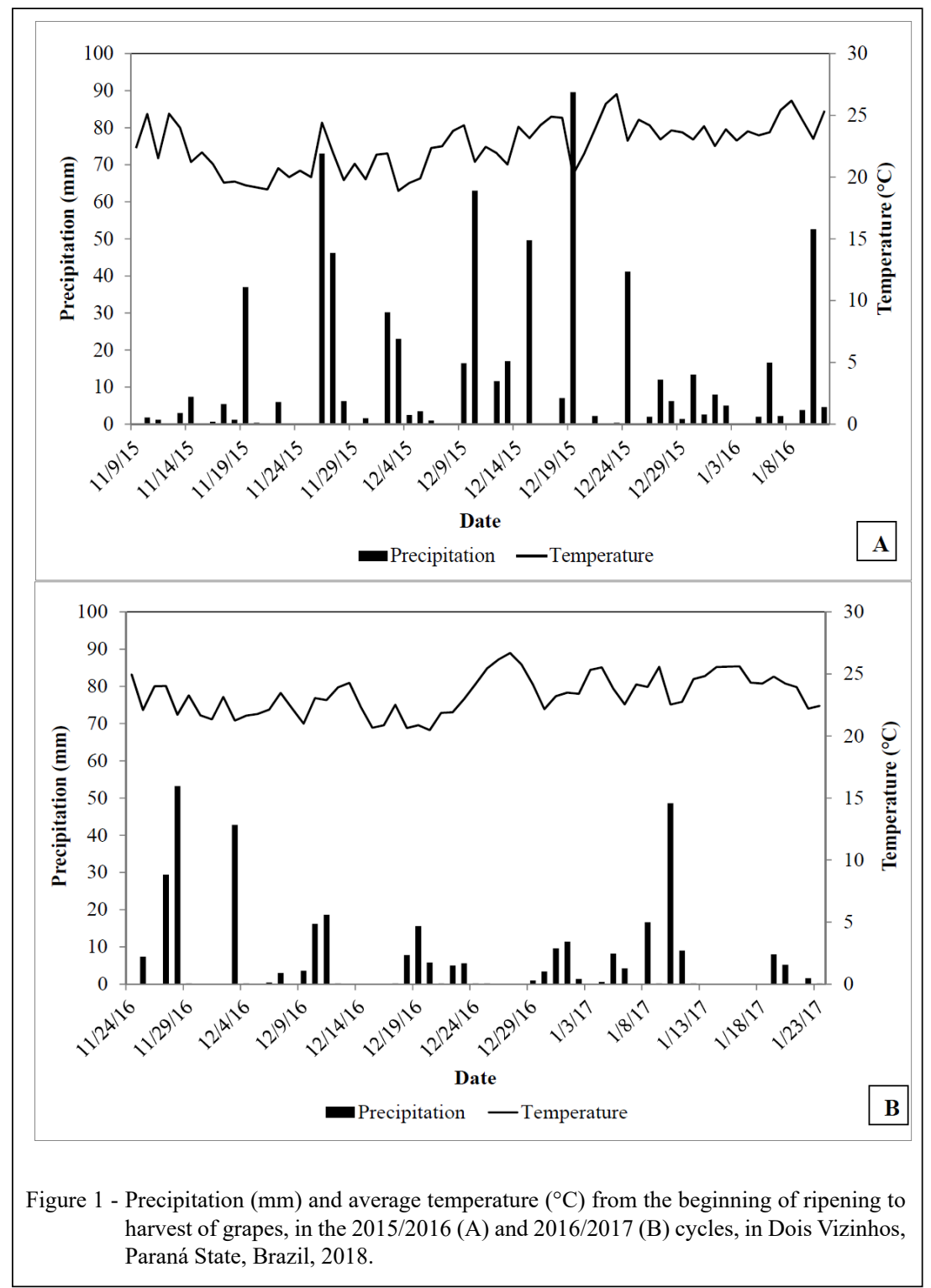

reported a higher average thermal requirement for the Isabel cultivar (1,900 degree-days).

Statistical differences were reported between the cycle of the cultivars in the 2015/2016 and 2016/2017 harvest year. However, in the $2015 / 2016$ cycle, the heat requirement of the cultivars was greater than in the 2016/2017 cycle (Table 3 ). Again, it is worth mentioning that, as suggested by CITADIN et al. (2001) and PERUZZO et al. (2014), the lower the natural supply of cold conditions in the winter, the greater the heat requirement for the vines to sprout and develop shoots and bunches. It should be noted that the date of pruning in the 2015/2016 harvest year, in plants with possibly more dormant buds, might have interfered with the highest heat requirement, as suggested by NEIS et al. (2010).

\section{CONCLUSION}

We can conclude that, under the edaphoclimatic conditions of Dois Vizinhos, southwestern Paraná, Brazil, the cultivars Moscato Bailey and Seibel 5455 had high thermal requirements and longer cycles, while the cultivars BRS Magna, BRS Violeta, and Isabel Precoce had lower thermal requirements and shorter cycles. Cycles of the cultivars 
Table 3 - Period in days (cycle) and total thermal requirement (degree-days) of grapevine cultivars from the beginning of sprouting to harvesting, in the 2015/2016 and 2016/2017 cycles. Universidade Tecnológica Federal do Paraná, Dois Vizinhos, Paraná State, Brazil, 2018.

\begin{tabular}{|c|c|c|c|c|c|c|}
\hline \multirow[t]{2}{*}{ Cultivar/Cycle } & \multicolumn{3}{|c|}{ 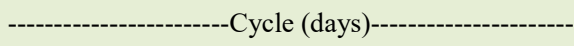 } & \multicolumn{3}{|c|}{--Total thermal requirement --1-_- } \\
\hline & $2015 / 2016$ & $2016 / 2107$ & Average & $2015 / 2016$ & $2016 / 2017$ & Average \\
\hline Bordô & $(-)$ & $(-)$ & $(-)$ & $(-)$ & $(-)$ & $(-)$ \\
\hline BRS Carmem & $114 \mathrm{~dB}^{*}$ & $122 \mathrm{cA}$ & 118 & $1,471 \mathrm{aA}$ & $1,373 \mathrm{bB}$ & 1,422 \\
\hline BRS Lorena & $128 \mathrm{bA}$ & $124 \mathrm{cA}$ & 126 & $1,519 \mathrm{aA}$ & $1,370 \mathrm{bB}$ & 1,445 \\
\hline BRS Magna & $98 \mathrm{eA}$ & $98 \mathrm{fA}$ & 98 & $1,213 \mathrm{cA}$ & $1,116 \mathrm{~dB}$ & 1,165 \\
\hline BRS Rubea & $124 \mathrm{bB}$ & $133 \mathrm{bA}$ & 128 & $1,513 \mathrm{aA}$ & $1,510 \mathrm{aA}$ & 1,512 \\
\hline BRS Violeta & $99 \mathrm{eB}$ & $105 \mathrm{eA}$ & 102 & $1,175 \mathrm{cA}$ & $1,136 \mathrm{dA}$ & 1,156 \\
\hline Concord & $119 \mathrm{cB}$ & $126 \mathrm{cA}$ & 123 & $1,422 \mathrm{aA}$ & $1,065 \mathrm{~dB}$ & 1,244 \\
\hline Concord Clone 30 & $115 \mathrm{dA}$ & $116 \mathrm{dA}$ & 115 & $1,445 \mathrm{aA}$ & $1,243 \mathrm{cB}$ & 1,344 \\
\hline Isabel & $126 \mathrm{bA}$ & $129 \mathrm{bA}$ & 127 & $1,448 \mathrm{aA}$ & $1,494 \mathrm{aA}$ & 1,471 \\
\hline Isabel Precoce & $110 \mathrm{dA}$ & $105 \mathrm{eB}$ & 108 & $1,305 \mathrm{bA}$ & $1,125 \mathrm{~dB}$ & 1,215 \\
\hline Moscato Bailey & $132 \mathrm{aA}$ & $131 \mathrm{bA}$ & 132 & $1,487 \mathrm{aA}$ & $1,491 \mathrm{aA}$ & 1,489 \\
\hline Moscato Embrapa & $127 \mathrm{bA}$ & $131 \mathrm{bA}$ & 129 & $1,470 \mathrm{aA}$ & $1,465 \mathrm{aA}$ & 1,468 \\
\hline Niagara Branca & $116 \mathrm{dA}$ & $114 \mathrm{dA}$ & 115 & $1,360 \mathrm{bA}$ & $1,233 \mathrm{cB}$ & 1,297 \\
\hline Niagara Rosada & $125 \mathrm{bA}$ & $116 \mathrm{~dB}$ & 120 & $1,473 \mathrm{aA}$ & $1,258 \mathrm{cB}$ & 1,366 \\
\hline Seibel 5455 & $128 \mathrm{bB}$ & $146 \mathrm{aA}$ & 136 & $1,547 \mathrm{aA}$ & $1,548 \mathrm{aA}$ & 1,548 \\
\hline Average & 118 & 121 & 119 & 1,420 & 1,317 & 1,367 \\
\hline
\end{tabular}

*Means followed by the same lowercase letter in columns and followed by the same uppercase letter in rows are not significantly different from each other, based on the Scott-Knott test at $5 \%$ probability of error. (-) absence of production, $\mathrm{CV}=\mathrm{coefficient}$ of variation.

ranged from 98 to 132 days and thermal requirements ranged from 1,065 to 1,548 degree-days.

\section{ACKNOWLEDGEMENTS}

The authors thank Coordenação de Aperfeiçoamento de Pessoal de Nível Superior (CAPES) for concession of master's degree scholarship to the main author of the paper.

\section{DECLARATION OF CONFLICT OF INTERESTS}

The authors declare that they have no conflict of interest. The founding sponsors had no role in the design of the study, nor in the data collection, analyses, or interpretation of data, the writing of the manuscript, nor the decision to publish the results.

\section{AUTHORS' CONTRIBUTIONS}

JAM and GAN conceived, designed and performed the experiments; JAM carried out the field and lab analyses. GAN supervised and coordinated the experiments and data collection. GAN and DP performed statistical analyses of experimental data. JAM and GAN prepared the draft of the manuscript. All authors critically revised the manuscript and approved of the final version.

\section{REFERENCES}

ALVARES, C.A. et al. Köppen's climate classification map for Brazil. Meteorologische Zeitschrift. v.22, n.6, p.711-728, 2013. Available from: <http://www.ingentaconnect.com/content/schweiz/ $\mathrm{mz} / 2013 / 00000022 / 00000006 /$ art00008?token $=004 \mathrm{fla} 11 \mathrm{bab} 2 \mathrm{a} 729 \mathrm{bc}$ 7e41225f40382d2c2b4652767446624550576b34272c5f7b3d6d3f4e 4b34a>. Accessed: Mar. 13, 2018. doi: 10.1127/0941-2948/2013/0507.

BACK, Á.J. et al. Mudanças climáticas e a produção de uva no vale do Rio do Peixe-SC. Revista Brasileira de Fruticultura, Jaboticabal, v.35, n.1, p.159-169, 2013. Available from: <http:// www.scielo.br/pdf/rbf/v35n1/19.pdf $>$. Accessed: Apr. 12, 2018. doi: 10.1590/S0100-29452013000100019.

BLOESCH, B.; VIRET, O. Stades phénologiques repères de la vigne. Revue Suisse Viticulture, Arboriculture, Horticulture, Croft, v.40, n.6, p.1-4, 2008. Available from: <http://www. agrometeo.ch/sites/default/files/documents/stades pheno vigne. pdf>. Accessed: Jul. 17, 2019.

BRIGHENTI, A.F. et al. Caracterização fenológica e exigência térmica de diferentes variedades de uvas viníferas em São Joaquim, Santa Catarina - Brasil. Ciência Rural, Santa Maria, v.43, p.1162-1167, 2013. Available from: <http://www.scielo.br/scielo. php?script $=$ sci_arttext\&pid=S0103-84782013000700004\&lng= en\&nrm=iso\&tlng=pt>. Accessed: Jun. 23, 2018. doi: 10.1590/ S0103-84782013005000082. 
CARVALHO, E. Fenologia, exigência térmica e produção de cultivares de videiras (Vitis spp.) em Lavras - MG. 2016 63f. Tese (Doutorado em Agronomia/Fitotecnia). Universidade Federal de Lavras.

CITADIN, I.; RASEIRA, M.C.B.; HERTER, F.G.; SILVA, J.B. Heat requirement for blooming and leafing in peach. HortScience, Alexandria, v.36, n.2, p.305-307, 2001. Available from: <https://journals.ashs.org/hortsci/view/ journals/hortsci/36/2/article-p305.xml>. Accessed: Aug. 07, 2018. doi: 10.21273/HORTSCI.36.2.305.

CRUZ, C.D. Programa Genes: estatística experimental e matrizes. Viçosa, Universidade Federal de Viçosa. 285p. 2006.

FERREIRA, E.A. et al. Antecipação de safra para videira Niágara Rosada na região sul do Estado de Minas Gerais. Ciência e Agrotecnologia, v.28, n.6, p.1221-1227, 2004. Available from: $<$ http://www.scielo.br/scielo.php?script=sci_arttext\&pid=S141370542004000600001\&lng $=\mathrm{en} \& \mathrm{nrm}=\mathrm{iso} \& \operatorname{tn} \mathrm{ln}=\mathrm{pt}>$. Accessed: Oct. 10, 2018. doi: 10.1590/S1413-70542004000600001.

GIOVANNINI, E. Produção de uvas para vinho, suco e mesa. Ed 3. Porto Alegre. Ed. Renascença, 2008. 362p.

INMET (2017). Instituto Nacional de Meteorologia. Available from: <http://www.inmet.gov.br/sonabra/pg_dspDadosCodigo_ sim.php?QTg0Mw>. Accessed: Aug. 15, 2017.

JUBILEU, B.S. et al. Caracterização fenológica e produtiva das videiras 'Cabernet Sauvignon' e 'Alicante' (Vitis vinifera L.) produzidas fora de época, no norte do Paraná. Revista Brasileira de Fruticultura, Jaboticabal, v.32, n.2, p.451-462, 2010. Available from: $<$ http://www.scielo.br/pdf/rbf/v32n2/aop05410.pdf $>$. Accessed: Jul. 09, 2018. doi: 10.1590/S0100-29452010005000051.

LEÃO, P.C.S. et al. Caracterização fenológica e requerimentos térmicos de variedades de uvas sem sementes no Vale do São Francisco. Revista Brasileira de Fruticultura, Jaboticabal, v.25, n.3, p.379-382, 2003. Available from: <http://www.scielo.br/pdf/ rbf/v25n3/18647.pdf>. Accessed: May. 19, 2018. doi: 10.1590/ S0100-29452003000300004.

MANDELLI, F. et al. Fenologia da videira na Serra Gaúcha. Pesquisa Agropecuária Gaúcha, Porto Alegre, v.9, n.1-2, p.129144, 2003. Available from: <http://www.revistapag.fepagro.rs.gov. br/files/PAG9n1e2.pdf>. Accessed: Aug. 13, 2017.

MANDELLI, F. et al. Fenologia e necessidades térmicas da videira na Serra Gaúcha. In: Congresso Brasileiro de Fruticultura, 20. Florianópolis, Anais..., v.18. 2004. CD-ROM.

MANDELLI, F. et al. Uva em clima temperado. Agrometeorologia dos cultivos; o fator meteorológico na produção agrícola. Instituto Nacional de Meteorologia INMET. p. 504-515, Brasília, 2009.
NAVA, G.A. Disponibilidade de frio hibernal para cultivo de fruteiras de clima temperado em Dois Vizinhos, Sudoeste do Paraná. In: Simpósio Brasil Sul de Fruticultura, 1. Chapecó, Anais..., p.75-75, 2015.

NEIS, S. et al. Caracterização fenológica e requerimento térmico para a videira Niágara Rosada em diferentes épocas de poda no Sudoeste Goiano. Revista Brasileira de Fruticultura, v.32, p.931-937, 2010. Available from: <http://www.scielo.br/scielo. php?script=sci_arttext\&pid=S0100-29452010000300038\&lng= en\&nrm=iso\&tlng=pt>. Accessed: Jun. 18, 2018. doi: 10.1590/ S0100-29452010005000081.

NUNES, N.A.S. et al. Phenology, reproductive biology and growing degree-days of the grapevine 'Isabel' (Vitis labrusca, Vitaceae) cultivated in northeastern Brazil. Brazilian Journal of Biology. Pernambuco, v.76, n.4, p.975-982, 2016. Available from: $<$ http://www.scielo.br/scielo.php?script=sci abstract\&pid=S1519$69842016000400975 \& \operatorname{lng}=$ en $\&$ nrm $=$ iso\&tlng $=p t>$. Accessed: Aug. 23, 2018. doi: 10.1590/1519-6984.05315.

PERUZZO, S.N. et al. Necessidade de horas de frio para superação da endodormência em cultivares Vitis labrusca L. In: Salão de iniciação científica e inovação tecnológica, 4. Bento Gonçalves, Anais..., 2014.

ROBERTO, S. R. et al. Caracterização da fenologia e exigência térmica (graus-dias) para a uva 'Cabernet Sauvignon' em zona subtropical. Acta Scientiarum Agronomy, Maringá, v.27, n.1, p.183-187, 2005. Available from: <http://periodicos.uem.br/ojs/ index.php/ActaSciAgron/article/view/2144>. Accessed: Sep. 08, 2018. doi: 10.4025/actasciagron.v27i1.2144.

SANTOS, C.E. et al. Caracterização da fenologia e da demanda térmica das videiras 'Cabernet Sauvignon' e 'Tannat' para a região norte do Paraná. Acta Scientiarum Agronomy, Maringá, v.29, n.3, p.361-366, 2007. Available from: <http://periodicos.uem.br/ ojs/index.php/ActaSciAgron/article/view/288>. Accessed: Apr. 21, 2018. doi: 10.4025/actasciagron.v29i3.288.

SENTELHAS, P.C. Aspectos climáticos para a viticultura tropical. Informe Agropecuário, Belo Horizonte, v.19, n.194. p.9-14, 1998. Available from: <http://www.epamig.br/download/ia_194_ viticultura-tropical_1998/>. Accessed: Jun. 11, 2018.

SOUZA, A.P. et al. Temperaturas basais e soma térmica para a figueira podada em diferentes épocas. Revista Brasileira de Fruticultura, Jaboticabal, v.31, n.2, p.314-322, 2009. Available from: <http:// www.scielo.br/scielo.php?script $=$ sci_arttext\&pid $=$ S 0100 $29452009000200005 \& \operatorname{lng}=$ en\&nrm $=$ iso\&tlng $=p t>$. Accessed: May, 24, 2018. doi: 10.1590/S0100-29452009000200005.

VILLA NOVA, N.A et al. Estimativa de graus-dia acumulados acima de qualquer temperatura base em função das temperaturas máxima e mínima. Instituto de Geografia, Universidade de São Paulo, n.30, p.1-8, 1972 (Caderno de Ciência da Terra) 